\title{
Haemophilus parahaemolyticus, Penicillinase Negative
}

National Cancer Institute

\section{Source}

National Cancer Institute. Haemophilus parahaemolyticus, Penicillinase Negative. NCI

Thesaurus. Code C123483.

Any bacterial species identified as Haemophilus parahaemolyticus that does not produce the enzyme penicillinase. 